\title{
Distribution of oligochaetes in a stream in the Atlantic Forest in southeastern Brazil
}

\author{
Rosa, BFJV ${ }^{a *}$, Martins, $R T^{b}$ and Alves, $R G^{c}$ \\ a'Laboratório de Invertebrados Bentônicos - LIB, Programa de Pós-Graduação em Ecologia - PGECOL, \\ Instituto de Ciências Biológicas - ICB, Universidade Federal de Juiz de Fora - UFJF, Campus Universitário, \\ Rua José Lourenço Kelmer, São Pedro, CEP 36036-330, Juiz de Fora, MG, Brazil \\ ${ }^{b}$ Coordenação de Biodiversidade, Instituto Nacional de Pesquisas da Amazônia - INPA, \\ Av. André Araujo, 2936, CP 478, CEP 69067-375, Manaus, AM, Brazil \\ 'Laboratório de Invertebrados Bentônicos - LIB, Departamento de Zoologia, Instituto de Ciências Biológicas - ICB, \\ Universidade Federal de Juiz de Fora - UFJF, CEP 36036-330, Juiz de Fora, MG, Brazil \\ *e-mail: beatrizjabour@yahoo.com.br
}

Received: November 20, 2013 - Accepted: December 18, 2013 - Distributed: March 31, 2015

(With 3 figures)

\begin{abstract}
The oligochaetes are considered good indicators of ecological conditions and specific types of habitats. Among the factors that influence the distribution of these invertebrates are the water flow and the nature of the substrate. The aim of this study is to describe the composition and distribution of oligochaete species in a first-order stream in Atlantic Forest and try to identify if some species are associated with characteristics of particular types of habitats. In the dry season and in the rainy season, sand and litter samples in two riffle areas and two pool areas were collected in different parts along the stream using a hand net. The greatest observed richness and abundance occurred in sand in the pool, however the greatest estimated richness was obtained for litter in the pool. The Kruskal-Wallis analysis showed effect of the different types of habitat on the abundance and richness of oligochaetes. The Nonmetric Multidimensional Scaling (NMDS) and Multiresponse Permutation Procedure analysis (MRPP) indicated that the variation in the fauna composition had relation with different types of substrates. The indicator species analysis showed that Limnodrilus. hoffmeisteri was an indicator species in both the riffle sand and pool sand and Pristina americana was only an indicator in the pool sand. The high organic matter content in both sandy habitats probably favored the greater abundance of oligochaetes. The results showed that the substrate constitutes an important factor for the local distribution of these invertebrates in streams. The variation of the community structure among mesohabitats and the presence of indicator species of specific types of habitats in the stream demonstrate the importance of environmental heterogeneity for the oligochaetes fauna in forested streams.
\end{abstract}

Keywords: indicator species, litter, sand, tropical region.

\section{Distribuição de oligoquetas em um riacho da Mata Atlântica, Sudeste do Brasil}

\section{Resumo}

Os oligoquetos são considerados bons indicadores de condições ecológicas e de tipos específicos de habitats. Entre os principais fatores que influenciam a distribuição desses invertebrados estão o fluxo da água e a natureza do substrato. O objetivo principal desse estudo foi descrever a composição e distribuição de espécies de oligoquetas de um riacho de primeira ordem da Mata Atlântica e identificar espécies que são características de tipos específicos de habitats. Na estação seca e na estação chuvosa, amostras de areia e folhiço de duas corredeiras e dois remansos foram coletadas em diferentes manchas ao longo de um trecho do riacho usando rede de mão. A maior abundância e riqueza observada ocorreram em areia de remanso. Entretanto, a análise de rarefação mostrou que a maior riqueza estimada foi obtida em folhiço de remanso. A análise de Kruskal-Wallis mostrou o efeito dos diferentes tipos de mesohabitats sobre a abundância e riqueza de oligoquetas. A análise de Escalonamento Multidimensional não- Métrico (NMDS) e a análise de Procedimento de permutação mulitirespostas (MRPP) indicaram que a variação na composição da fauna teve relação com os diferentes tipos de substratos. A análise de espécies indicadoras mostrou que L. hoffmeisteri foi indicadora tanto de areia de corredeira como de remanso e P. americana foi indicadora somente de areia de remanso. O alto conteúdo de material orgânico em ambos habitats arenosos provavelmente favoreceu a maior abundância de oligoquetos. Os 
resultados mostraram que o substrato constitui um importante fator para a distribuição local desses invertebrados em riachos. A variação da estrutura da comunidade entre os mesohabitats e a presença de espécies indicadoras de tipos específicos de habitats demonstrou a importância da heterogeneidade ambiental para a riqueza e distribuição de oligoquetos em riachos florestados.

Palavras-chave: espécies indicadoras, folhiço, areia, região tropical.

\section{Introduction}

The interaction of environmental variables in different scales of time and space determines the structure of the benthic communities in streams (Brosse et al., 2003; Weigel et al., 2003). The climate and geology of the watershed determine vegetation types, rainfall regime, temperature, substrate characteristics and water flow conditions. Variations in water speed influence the size of particles in the substrate, distribution of food resources and formation of different mesohabitats on the stream bed, determining the distribution of benthic organisms (Pardo and Armitage, 1997; Beisel et al., 1998). The relationship of benthic fauna with specific habitats makes these organisms efficient indicators of patterns of water flow, types of prevailing substrates and temporal or anthropic changes, which normally alter those factors (Verdonschot, 2001; Muotka and Laasonen, 2002).

The oligochaetes, as well as other aquatic invertebrates, can also live in habitats with a wide range of ecological conditions, from aquatic environments strongly impacted by human activities (Juget and Lafont, 1994; Martins et al., 2008) to conserved habitats where the entry of organic matter is basically restricted to litter from nearby plants, such as those present in riparian forests in mountain streams (Dumnicka, 1994). In natural environments the main factors that influence the occurrence and distribution of oligochaetes are the structure of the substrate, organic matter content and water flow. For instance, there are species that prefer substrates with smaller particle size and low current flow, while others are more common in habitats with coarser substrates and higher flow (Verdonschot, 2001; Dumnicka, 2006; Syrovátka et al., 2009).

Oligochaetes are good indicators of conditions and specific types of habitats (Verdonschot, 2001), and are thus commonly used in ecological characterization studies. The distribution pattern of these invertebrates in neotropical lotic environments is still relatively unknown, especially in small streams in the Atlantic Forest (Alves et al., 2008).

Since benthic organisms have varied responses to the physical variables of aquatic habitats, studies of the composition and distribution of different groups of invertebrates provides a better understanding of the relationship of this fauna with the organization and structure of the lotic ecosystem. Based on the hypothesis that oligochaetes species have specific preferences for stream habitats, the aim of this study is to describe the composition and distribution of oligochaetes species in a first-order stream in the Atlantic Forest region and to identify the species that are characteristic of particular types of habitats, considering the substrate and water flow as the main variables.

\section{Material and Methods}

The stream is located in a fragment of the Atlantic Forest in the secondary succession stage $\left(21^{\circ} 44^{\prime} 36^{\prime \prime}-21^{\circ} 44^{\prime}\right.$ $31^{\prime \prime} \mathrm{S}$ and $43^{\circ} 18^{\prime} 51^{\prime \prime}-43^{\circ} 18^{\prime} 53^{\prime \prime} \mathrm{W}$, at an altitude of $850 \mathrm{~m}$ ) in Juiz de Fora, southeastern Brazil. The climate in the region is Cwa in the Köppen classification, with hot and rainy summers and cool and dry winters (Latuf, 2004). It is shallow $(5.63 \pm 1.43 \mathrm{~cm})$ and the streambed is mostly composed of sand with average organic matter content of $30 \%$, predominance of $2 \mathrm{~mm}$ to $0.5 \mathrm{~mm}$ fractions in riffles and $2 \mathrm{~mm}$ to $0.25 \mathrm{~mm}$ in pools (Table 1) and patches of stones and leaf litter.

The water is transparent and well oxygenated $(10.03 \pm 0.42 \mathrm{mg} / \mathrm{L})$, with good electric conductivity $(17.75 \pm 2.06 \mu \mathrm{S} / \mathrm{cm})$ and $\mathrm{pH}$ of $6.38 \pm 0.41$. These variables are the average of three readings at each collection point along the stream, using a Horiba U10 multiparameter meter. Differences between the measures of environmental variables were estimated by the Mann-Whitney test $(p<0.05)$. In each of three months in the dry season (July, August and September) and three in the rainy season (January, February and March), sand and litter samples in two riffles and two pools along a segment of approximately $100 \mathrm{~m}$ of the stream were collected for a period of 30 seconds each, using a hand net (250 $\mu \mathrm{m}$ mesh). Two monthly samples were thus obtained from each mesohabitat: Litter in pool, litter in riffle, sand in pool and sand in riffle. The pools and riffles sampled were different from month to month.

The samples were fixed in $4 \%$ formaldehyde and the organisms were sorted under a stereoscopic microscope and conserved in $70 \%$ alcohol. The oligochaetes were identified under an optical microscope to the lowest taxonomic level possible, according to the criteria suggested by Brinkhurst and Jamieson (1971), Righi (1984) and Brinkhurst and Marchese (1992). The species formerly considered to be included in the family Tubificidae were instead classified as belonging to the family Naididade, according to Erséus et al. (2008).

Table 1. Granulometric characterization of sediment (ABNT, 1995) in the stream located in an Atlantic Forest fragment area in southeastern Brazil.

\begin{tabular}{lcc}
\hline \multicolumn{1}{c}{ Particle size (\%) } & $\begin{array}{c}\text { Pool } \\
\text { sediment }\end{array}$ & $\begin{array}{c}\text { Riffle } \\
\text { sediment }\end{array}$ \\
\hline $20 \geq \Phi>2 \mathrm{~mm}$ (fine gravel) & 15.88 & 36.84 \\
$2 \geq \Phi>0.5 \mathrm{~mm}$ (coarse sand) & 35.60 & 39.88 \\
$0.5 \geq \Phi>0.25 \mathrm{~mm}$ & 29.39 & 16.05 \\
(medium sand) & & \\
$0.25 \geq \Phi>0.05 \mathrm{~mm}$ (fine sand) & 18.10 & 6.92 \\
$\Phi \leq 0.05 \mathrm{~mm}$ (silt) & 1.01 & 0.31 \\
\hline
\end{tabular}


For each mesohabitat we measured the abundance and both observed and estimated richness. The richness was estimated by rarefaction curves for the four mesohabitats sampled based on the lowest abundance of individuals obtained (Gotelli and Cowell, 2001), using the EcoSim (version 7.72) program. When the criteria normality were not met (Shapiro-Wilk test, $\mathrm{p}>0.05$ ) or the homoscedasticity of the variances were not obtained (Levene test, $\mathrm{p}>0.05$ ), we used KruskalWallis analysis $(p<0.05)$ to determine the effect of different mesohabitats on the variation of abundance and richness observed. The Mann-Whitney test $(p<0.05)$ was used to check the effect of the seasons (dry and rainy) on these parameters. The analyses was carried out with the Statistica (version 7.0) program. Since in streams the dynamics between habitats and periods have a stochastic component (Townsend, 1989; Lake, 2000), we assumed independence between the samples.

We performed non-metric multidimensional scaling (NMDS) to verify the ordination of the fauna in the mesohabitats from the log-transformed abundance data. In this analysis, sample units that did not contain oligochaete specimens were excluded. Significant differences in the fauna composition between the mesohabitats were checked by the nonparametric multi-response permutations procedure (MRPP). These analyses were performed with the PC-ORD 5.15 program (McCune and Mefford, 2006).

We also applied analysis of similarity (Anosim) to test the variation in the fauna composition between the two seasons and calculated the indicator value (IndVal), as proposed by Dufrene and Legendre (1997), to verify the existence of taxa with preferences for a determined type of mesohabitat. This method combines information on species abundance and frequency of occurrence among groups. A taxon is considered to be a good indicator when it has high abundance and frequency of occurrence in one of the conditions defined a priori. These analyses were performed with the $\mathrm{R}$ program ( $\mathrm{R}$ Development Core Team, 2011).

\section{Results}

The average water speed in the stream's riffles was $0.23 \pm 0.33 \mathrm{~m} / \mathrm{s}$, with a significant difference between the two seasons $(Z=2.93 ; n=6 ; p<0.01)$ and riffle and pool areas $(Z=-2.99 ; n=6 ; p<0.01)$, but the abiotic variables of the water did not vary significantly between the mesohabitats: $\mathrm{pH}(\mathrm{Z}=0.382 ; \mathrm{n}=6 ; \mathrm{p}=0.38)$, conductivity $(\mathrm{Z}=1.556 ; \mathrm{n}=6$; $\mathrm{p}=0.12)$ and dissolved oxygen $(\mathrm{Z}=0.872 ; \mathrm{n}=6 ; \mathrm{p}=0.38)$.

We found 343 oligochaetes specimens, belonging to three families: Alluroididae, Enchytraeidae and Naididae. The most abundant species were Limnodrilus hoffmeisteri and Pristina americana, which occurred predominantly in the sand in pool. In the litter in riffle and litter in pool, the family Enchytraeidae was best represented in the dry season, although the greatest abundance of this family occurred in sand in riffle (Table 2).

The greatest observed richness occurred in the sand in pool $(\mathrm{p}>0.05)$ but the rarefaction analysis indicated that the greatest estimated richness occurred in the litter in pool (Figure 1). This demonstrates the influence of the abundance obtained in the sand in pool over the observed richness for this mesohabitat.

The Kruskal-Wallis analysis showed the effect of the different types of habitat on the abundance $(\mathrm{H}=18.85$; $\mathrm{df}=3 ; \mathrm{p}<0.01)$ and richness of oligochaetes $(\mathrm{H}=24.35$; $\mathrm{df}=3 ; \mathrm{p}<0.01$ ), allowing us to verify that sand substrates presented higher abundance and richness than litter substrates (Figure 2). However, the Mann-Whitney test showed that only richness decreased significantly between seasons $(Z=2.51 ; n=32 ; p=0.01)$.

In the NMDS analysis we observed that the riffle sand and pool sand mesohabitats tend to form a more homogeneous group (Figure 3). The MRPP analysis indicated variation in the fauna composition between mesohabitats with different types of substrates, except the riffle sand and riffle litter (Table 3). But we did not detect any variation in the fauna composition between the two seasons $(R=0.07 ; p=0.11)$.

The indicator species analysis showed that L. hoffmeisteri was an indicator species in both the riffle sand and pool sand $(\mathrm{IV}=0.914 ; \mathrm{p}<0.01)$ and $P$. americana was an indicator in only the pool sand (IV=0.713; $=0.02)$.

Table 2. Abundance and observad richness Oligochaetes collected in dry and rainy seasons in mesohbitats: Sand in pool (SP), sand in riffle (SR), litter in riffle (LR) and litter in pool (LP) in a stream located in an Atlantic Forest fragment area in southeastern Brazil.

\begin{tabular}{|c|c|c|c|c|c|c|c|c|}
\hline \multirow{2}{*}{$\begin{array}{c}\text { Season } \\
\text { Habitat }\end{array}$} & \multicolumn{4}{|c|}{ Dry } & \multicolumn{4}{|c|}{ Rainy } \\
\hline & SP & SR & LR & $\mathbf{L P}$ & SP & SR & LR & $\mathbf{L P}$ \\
\hline Alluroidea & 1 & - & 2 & 1 & 1 & 1 & - & - \\
\hline Enchytraeidae & 17 & 39 & 15 & 11 & 8 & 7 & - & 6 \\
\hline Naididae (Sensu Erséus et al., 2008) & & & & & & & & \\
\hline Pristina proboscidea Beddard 1895 & 1 & - & - & - & - & - & - & - \\
\hline Pristina americana Cernosvitov, 1937 & 7 & 2 & - & 1 & 27 & 10 & - & - \\
\hline Pristinella jenkinae (Stephenson, 1931) & - & - & - & - & 1 & - & - & 1 \\
\hline Limnodrilus hoffmeisteri Claparede, 1862 & 116 & 20 & 3 & - & 22 & 10 & - & 2 \\
\hline Bothrioneurum sp. Stolc 1888 & 3 & 5 & - & - & 8 & 1 & - & - \\
\hline Observad Richness & 7 & 6 & 3 & 3 & 6 & 5 & - & 3 \\
\hline
\end{tabular}




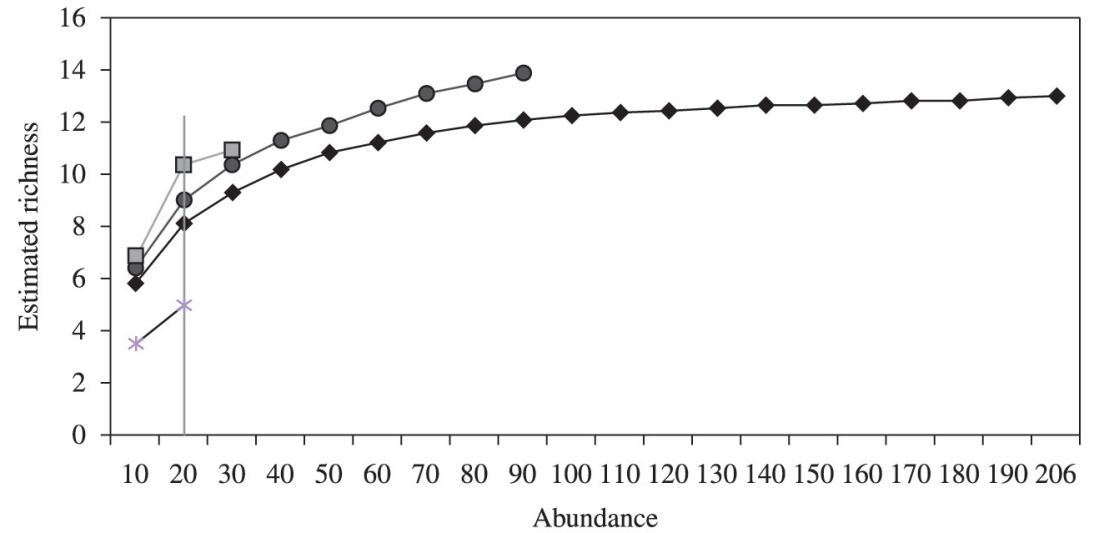

$\neg-$ Sand pool $\multimap-$ Sand riffle $\multimap$ Litter pool $\rightarrow \leftarrow$ Litter riffle

Figure 1. Estimated richness of oligochaetes in the two mesohabitats (pool and riffle) in a stream located in an Atlantic Forest fragment area in southeastern Brazil. The vertical bar indicates the lowest abundance obtained.
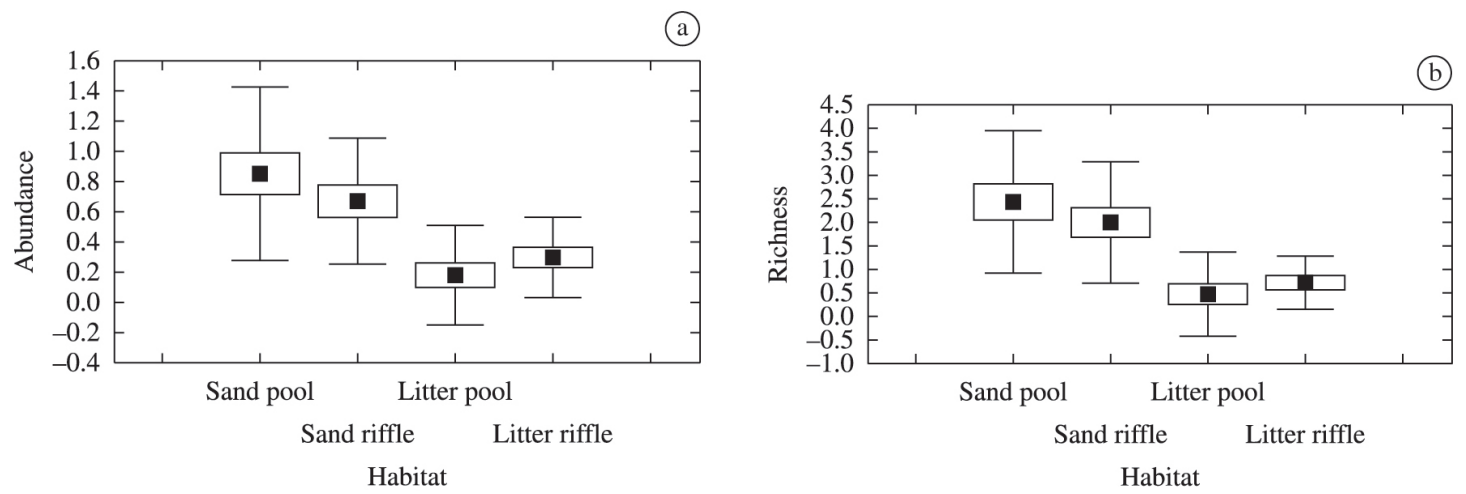

- Mean $\square$ Mean \pm SE I Mean \pm SD

Figure 2. Result of the Kruskal-Wallis analysis showing the effect of the different mesohabitats types on the abundance and richness of oligochaetes in a stream located in an Atlantic Forest fragment area in southeastern Brazil.

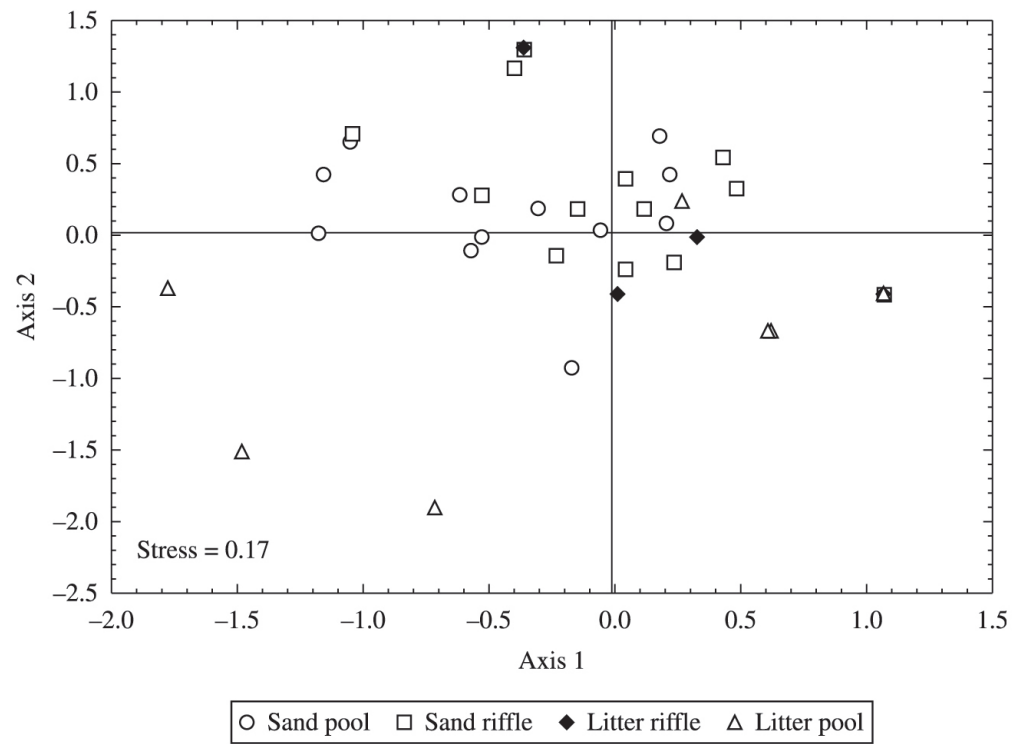

Figure 3. Non-metric multidimensional scaling (NMDS) analysis, showing the ordination of the mesohabitats in a stream located in an Atlantic Forest fragment area in southeastern Brazil. 
Table 3. Result of the multi-response permutation procedure (MRPP) of the oligochaetes fauna collected in a stream located in an Atlantic Forest fragment area in southeastern Brazil. RL- riffle litter, PL- pool litter, PS- pool sand, RS- riffle sand.

\begin{tabular}{lrr}
\hline Group codes compared & \multicolumn{1}{c}{$\mathbf{A}^{*}$} & \multicolumn{1}{c}{ P } \\
\hline PS vs. RS & 0.002 & 0.37 \\
PS vs. RL & 0.030 & 0.05 \\
PS vs. PL & 0.070 & $<\mathbf{0 . 0 1}$ \\
RS vs. RL & -0.011 & 0.63 \\
RS vs. PL & 0.036 & 0.03 \\
RL vs. PL & -0.022 & 0.71 \\
\hline
\end{tabular}

*Chance-corrected within-group agreement.

\section{Discussion}

Studies of streams show that more complex substrates such as leaves and other plant matter generally contain greater abundance and richness of oligochaetes, by providing more spots for shelter and retaining more abundant food resources, in the form of small organic particles and periphyton (Dangles et al., 2001; Taniguchi and Tokeshi, 2004; Gorni and Alves, 2012). However, this association was not observed in the stream studied here, as shown by the results of the Kruskal-Wallis, which indicated greater taxon abundance and richness values associated with the sandy substrate in both the riffles and pools. The high organic matter content in both sandy habitats probably favored the greater abundance of oligochaetes, which in turn influenced the greater richness observed in this substrate. On the other hand, there was no variation of the fauna in relation to the water flow differences between the mesohabitats (riffle and pool). This result corroborates that of Syrovátka et al. (2009), who reported that the quantity of particulate organic matter explained more of the variation observed in the oligochaetes fauna than did the water flow conditions. Alves et al. (2006) and Verdonschot (2001) respectively observed that the granulometria and nature of the substrate has a considerable influence on the distribution of oligochaetes. According to Ward (1992), substrate characteristics are a more effective variable to explain the distribution of benthic species than the physical and chemical properties of the water. Additionally, the greater abundance and frequency of L. hoffmeisteri, Bothrioneurum sp. and P. americana in sandy mesohabitats contributes to the variation observed in the composition of oligochaetes species, confirming that differences related to the substrate constitute an important factor for the distribution of these invertebrates in natural water bodies (Sauter and Gude, 1996).

Limnodrilus hoffemeisteri has been found by other authors associated with fine sediment (Marchese and Drago, 1999; Alves and Strixino, 2000). In the stream studied here this species was present in sediment consisting mainly of coarse and medium sand fractions. This may have been favored by the ability of L. hoffmeisteri to colonize sediments with a wide variety of granulometric fractions (Sauter and Gude, 1996).

Pristina americana, considered as indicator of sandy pool sediment, was found in tributaries of the Paraná River in habitats with varied granulometry, from pebbles to sand and mud (Takeda, 1999). Suriani-Affonso et al. (2011) found this species to be mostly associated with habitats containing a predominance of medium sand in the rivers studied, and Learner et al. (1978) observed that Pristina species were mainly associated with gravel substrate. These studies taken together show the plasticity of this species in colonizing habitats with varied substrate and flow.

Enchytraeidae, the family with the most homogeneous distribution in all the mesohabitats, is generally abundant in streams with coarse granulometry and high oxygen content (Lencioni and Maiolini, 2002), characteristics also present in the stream studied here. Many Enchytraeidae species are able to colonize habitats with varied conditions, including those with faster water flow and substrates with large particles (Giani and Lavandier, 1977; Johnson and Ladle, 1989) because the large interstitial spaces provide good oxygenation (Giere, 1993).

The increased rainfall and consequent faster flow in the wet season is one of the main factors causing variation in the structure of benthic communities in tropical streams (Ribeiro and Uieda, 2005; Carvalho and Uieda, 2004; Battistoni et al., 2010). Our results, however, indicate that only the rich taxa (Enchytraeidae) were vulnerable to increased precipitation. In agreement, Takeda (1999) did not observe seasonal effects on the abundance of oligochaetes in habitats located in the alluvial plain of the Paraná River, but suggested that water level fluctuations are an important factor for the colonization patterns of oligochaetes species. Verdonschot (2001) reported that although the distribution of oligochaetes in streams is affected by a complex interaction of variables, the hydrological regime is an important additional variable to explain the species distribution of this community.

The variation of the community structure among the types of mesohabitats and the presence of indicator species of specific types of habitats in the stream studied demonstrate the importance of heterogeneity for oligochaetes fauna in streams in forested regions. On the other hand, the low total abundance of individuals found in this study can be explained by the presence of potential predators of oligochaetes, such as odonatan and megalopteran insects. These orders were found in this steam by Rosa et al. (2009) during the same period and with the same substrate types. Alves et al. (2008) also found low abundance of oligochaetes ( $n=259$ individuals $)$ in forest streams with cold and well oxygenated water, the beds being made up mainly by pebbles and accumulation of fine and coarse organic matter. In organically polluted environments, unlike in the stream studied here, it is common to find a great abundance of worms, possibly favored by the absence of more sensitive organisms and elimination of competition and predation (Myslinski and Ginsburg, 1977; Martins et al., 2008). 
The results demonstrate that in the stream studied the oligochaetes species have preferences for specific types of habitats, with the substrate being the component with the greatest influence on the distribution of these invertebrates. Considering the low representation of oligochaetes in this stream and in other environments with similar characteristics, there is a need for further studies to investigate the distribution of these organisms. And given the different types of substrates and flows (Verdonschot, 2001), these become important predictors of the richness and diversity of species in preserved loworder lotic environments.

\section{Acknowledgements}

We would like to thank the Minas Gerais State Research Foundation (FAPEMIG) for the financial support and the National Council for Scientific and Technological Development $(\mathrm{CNPq})$ for ongoing support (grant numbers 303156/2012-0). The second author is grateful to Program Support Fixing Doctors at Amazon FIXAM/AM. The first author is grateful to CAPES for the scholarship.

\section{References}

ALVES, RG., MARCHESE, MR. and ESCARPINATI, SC., 2006. Oligochaeta (Annelida, Clitellata) in lotic environments in the state of São Paulo, Brazil. Iheringia. Série Zoologia, vol. 96, no. 4, p. 431-435. http://dx.doi.org/10.1590/S0073-47212006000400007.

ALVES, RG. and STRIXINO, G., 2000. Distribuição espacial de Oligochaeta do sedimento de uma lagoa marginal do rio Mogi-Guaçu-SP. Iheringia. Série Zoologia, vol. 88, p. 173-180.

ALVES, RG., MARCHESE, MR. and MARTINS, RT., 2008. Oligochaeta (Annelida, Clitellata) of lotic environments at Parque Estadual Intervales (São Paulo, Brazil). Biota Neotropica, vol. 8, no. 1, p. 69-72. http://dx.doi.org/10.1590/S1676-06032008000100009.

Associação Brasileira de Normas Técnicas - ABNT, 1995. NBR 6502/95: rochas e solos. Rio de Janeiro.

BATTISTONI, D., FAVASSA, CTA., TRIQUES, R., BARP, EA. and RODRIGUES, GG., 2010. Composição faunística de macroinvertebrados bentônicos ocorrentes na parte baixa do Rio Jacutinga, Concórdia, SC. Ágora: Revista de Divulgação Científica, vol. 17, p. 20-31.

BEISEL, JN., USSEGLIO-POLATERA, P., THOMAS, S. and MORETEAU, JC., 1998. Stream community structure in relation to spatial variation: the influence of mesohabitat characteristics. Hydrobiologia, vol. 389, no. 1/3, p. 73-88. http://dx.doi. org/10.1023/A:1003519429979.

BRINKHURST, RO. and JAMIESON, BGM., 1971. Aquatic Oligochaeta of the world. Toronto: University of Toronto. $860 \mathrm{p}$.

BRINKHURST, RO. and MARCHESE, M., 1992. Guia para la identificación de oligoquetos acuáticos continentales de Sud y Centroamérica. Santa Fe: Asociacíon de Ciências Naturales del Litoral. 207 p.

BROSSE, S., ARBUCKLE, CJ. and TOWNSEND, CR., 2003. Habitat scale and biodiversity: influence of catchment, stream reach and bedform scales on local invertebrate diversity. Biodiversity and Conservation, vol. 12, no. 10, p. 2057-2075. http://dx.doi. org/10.1023/A:1024107915183.

CARVALHO, EM. and UIEDA, VS., 2004. Colonização por macroinvertebrados bentônicos em substrato artificial e natural em um riacho da serra de Itatinga, São Paulo, Brasil. Revista Brasileira de Zoologia, vol. 21, no. 2, p. 287-293. http://dx.doi. org/10.1590/S0101-81752004000200021.

DANGLES, O., GUEROLD, F. and USSEGLIO-POLATERA, P., 2001. Role of transported particulate organic matter in the macroinvertebrate colonization of litter bags in streams. Freshwater Biology, vol. 46, no. 5, p. 575-586. http://dx.doi. org/10.1046/j.1365-2427.2001.00693.x.

DUFRÊNE, M. and LEGENDRE, P., 1997. Species assemblages and indicator species: the need for flexible asymmetrical approach. Ecological Monographs, vol. 67, p. 345-366.

DUMNICKA, E., 1994. Habitat preferences of invertebrates (especially Oligochaeta) in a stream. Acta Hydrobiologica, vol. 36, p. 91-101.

DUMNICKA, E., 2006. Composition and abundance of oligochaetes (Annelida: Oligochaeta) in springs of Krakow-Czestochowa Upland (Southern Poland): effect of spring encasing and environmental factors. Polish Journal of Ecology, vol. 54, p. 231-242.

ERSÉUS, C., WETZEL, MJ. and GUSTAVSON, L., 2008. ICZN rules: a farewell to Tubificidae (Annelida, Clitellata). Zootaxa, vol. 1744 , p. 66-68.

GIANI, N. and LAVANDIER, P., 1977. Les oligochètes du torrent d'Eslaragne (Pyrénées cenlrales). Bulletin de la Société d'Histoire Naturelle de Toulouse, vol. 1213, p. 234-243.

GIERE, O., 1993. Meiobenthology the microscopic fauna in aquatic sediments. Springer Verlag. 328 p.

GORNI, GR. and ALVES, RG., 2012. Oligoquetos (Annelida, Clitellata) em um córrego neotropical: uma abordagem do mesohabitat. Iheringia. Série Zoologia, vol. 102, no. 1, p. 106-110.

GOTELLI, N. and COLWELL, RK., 2001. Quantifying biodiversity: procedures and pitfalls in the measurement and comparison of species richness. Ecology Letters, vol. 4, no. 4, p. 379-391. http:// dx.doi.org/10.1046/j.1461-0248.2001.00230.x.

JOHNSON, P. and LADLE, M., 1989. The Enchytraeidae (Oligochaeta) of streams of Southern England. Annales de Limnologie, vol. 25, no. 2, p. 121-129. http://dx.doi.org/10.1051/ limn/1989012.

JUGET, J. and LAFONT, M., 1994. Theoretical habitat templets, species traits, and species richness: aquatic oligochaetes in the Upper Rhône River and its floodplain. Freshwater Biology, vol. 31, no. 3, p. 327-340. http://dx.doi.org/10.1111/j.1365-2427.1994. tb01744.x.

LAKE, PS., 2000. Disturbance, patchiness, and diversity in streams. Journal of the North American Benthological Society, vol. 19, no. 4, p. 573-592. http://dx.doi.org/10.2307/1468118.

LATUF, MO., 2004. Diagnóstico das águas superficiais do Córrego São Pedro, Juiz de Fora-MG. Geografia, vol. 13, p. 21-55.

LEARNER, MA., LOCHHEAD, G. and HUGHES, BD., 1978. A review of the biology of British Naididae (Oligochaeta) with emphasis on the lotic environment. Freshwater Biology, vol. 8, no. 4, p. 357-375. http://dx.doi.org/10.1111/j.1365-2427.1978. tb01457.x. 
LENCIONI, V. and MAIOLINI, B., 2002. L'ecologia di un ecosistema acquatico alpino (Val de la Mare, Parco Nazionale dello Stelvio). Natura Alpina, vol. 54, no. 4, p. 1-96.

MARCHESE, M. and DRAGO, IE., 1999. Use of benthic macroinvertebrates as organic pollution indicators in lotic environments of the Paraná River drainage basin. Polskie Archiwum Hydrobiologii, vol. 46, p. 233-255.

MARTINS, RT., STEPHAN, NNC. and ALVES, RG., 2008. Tubificidae (Annelida: Oligochaeta) as an indicator of water quality in an urban stream in southeast Brazil. Acta Limnologica Brasiliensia, vol. 20, p. 221-226.

MCCUNE, B. and MEFFORD, MJ., 2006. PC-ORD: multivariate analysis of ecological data. Version 5.10. Oregon: MjM Software.

MUOTKA, T. and LAASONEN, P., 2002. Ecosystem recovery in restored headwater streams: the role of enhanced leaf retention. Journal of Applied Ecology, vol. 39, no. 1, p. 145-156. http:// dx.doi.org/10.1046/j.1365-2664.2002.00698.x.

MYSLINSKI, E. and GINSBURG, W., 1977. Macro-invertebrates as indicators of pollution. Journal of the American Water Resources Association, vol. 69, p. 538-544.

PARDO, I. and ARMITAGE, PD., 1997. Species assemblages as descriptors of mesohabitats. Hydrobiologia, vol. 344, no. 1-2-3, p. 111-128. http://dx.doi.org/10.1023/A:1002958412237.

R Development Core Team, 2011. Language and Environment for Statistical Computing. Vienna: R Foundation for Statistical Computing.

RIBEIRO, LO. and UIEDA, VS., 2005. Estrutura da comunidade de macroinvertebrados bentônicos de um riacho de serra em Itatinga, São Paulo, Brasil. Revista Brasileira de Zoologia, vol. 22, no. 3, p. 613-618. http://dx.doi.org/10.1590/S0101-81752005000300013.

RIGHI, G., 1984. Oligochaeta. In SCHADEN, R. (Ed.). Manual de identificação de invertebrados límnicos do Brasil. Brasília: CNPq. 48 p.

ROSA, BFJV., MARTINS, RT., OLIVEIRA, VC. and ALVES, RG., 2009. Phoretic association between larvae of Rheotanytarsus (Diptera: Chironomidae) and genera of Odonata in a first-order stream in an area of Atlantic Forest in southeastern Brazil.
Iheringia. Zoologia, vol. 26, no. 4, p. 787-791. http://dx.doi. org/10.1590/S1984-46702009000400025.

SAUTER, G. and GUDE, H., 1996. Influence of grain size on the distribution of Tubificidae Oligochaeta species. Hydrobiologia, vol. 334, p. 97-101. http://dx.doi.org/10.1007/BF00017358.

SURIANI-AFFONSO, AL., FRANÇA, RS., MARCHESE, M. and ROCHA, O., 2011. Environmental factors and benthic Oligochaeta (Annelida, Clitellata) assemblages in a stretch of the Upper São Francisco River (Minas Gerais State, Brazil). Revista Brasileira de Biologia = Brazilian Journal of Biology, vol. 71, no. 2, p. 437-446. PMid:21755161.

SYROVÁTKA, V., SCHENKOVÁ, J. and BRABEC, K., 2009. The distribution of chironomid larvae and oligochaetes within a stony-bottomed river stretch: the role of substrate and hydraulic characteristics. Fundamental and Applied Limnology, vol. 174, no. 1, p. 43-62. http://dx.doi.org/10.1127/1863-9135/2009/0174-0043.

TAKEDA, AM., 1999. Oligochaeta community of alluvial Upper Paraná River, Brazil: spatial and temporal distribution (1987- 1988). Hydrobiologia, vol. 412, p. 35-42. http://dx.doi. org/10.1023/A:1003844131148.

TANIGUCHI, H. and TOKESHI, M., 2004. Effects of habitat complexity on benthic assemblages in a variable environment. Freshwater Biology, vol. 49, no. 9, p. 1164-1178. http://dx.doi. $\operatorname{org} / 10.1111 / \mathrm{j} .1365-2427.2004 .01257 . x$.

TOWNSEND, CR., 1989. The patch dynamics concept of stream community ecology. Journal of the North American Benthological Society, vol. 8, no. 1, p. 36-50. http://dx.doi.org/10.2307/1467400.

VERDONSCHOT, PFM., 2001. Hydrology and substrates:determinants of oligochaete distribution in lowland streams (The Netherlands). Hydrobiologia, vol. 463, no. 1-3, p. 249-262. http://dx.doi. org/10.1023/A:1013132514610.

WARD, JV., 1992. Aquatic insect ecology: biology and habitat. Chichester: John Wiley and Sons. 436 p.

WEIGEL, BM., WANG, L., RASMUSSEN, PW., BUTCHER, JT., STEWART, PM., SIMON, TP. and WILEY, MJ., 2003. Relative influence of variables at multiple spatial scales on stream macroinvertebrates in the Northern Lakes and Forest ecoregion, U.S.A. Freshwater Biology, vol. 48, no. 8, p. 1440-1461. http:// dx.doi.org/10.1046/j.1365-2427.2003.01076.x. 